\title{
MICROWAVE WAVEGUIDE POLARIZER WITH 3 POSTS
}

\section{S.I. Piltyay, PhD, Associate Professor; A.V. Bulashenko, Senior Lecturer; H.S. Kushnir, student \\ Igor Sikorsky Kyiv Polytechnic Institute, Kyiv, Ukraine}

Today, one of the key elements of antenna systems engaged in polarization signal processing are polarization devices. These devices are used to convert the types of polarization. The following designs of polarizers in the form of waveguide structures with posts [1], irises [2-4], ridged structures [5], polarizers with thin metal septum [6-7] are known. The designs of polarizing devices in the form of slots [8] are complex in design. Phase shifters also had such constructions [9]. The simplest from the design point of view and adjustable is a polarizer based on a waveguide with posts.

The design of the waveguide polarizer is shown in Fig. 1. The structure contains two posts of height $h_{1}$ and diameter $d$, one post of height $h_{2}$ and diameter $d$, the distance between the posts is $l$. Moreover, the height of the central post $h_{2}$ is greater than the height of the other posts $h_{l}$.
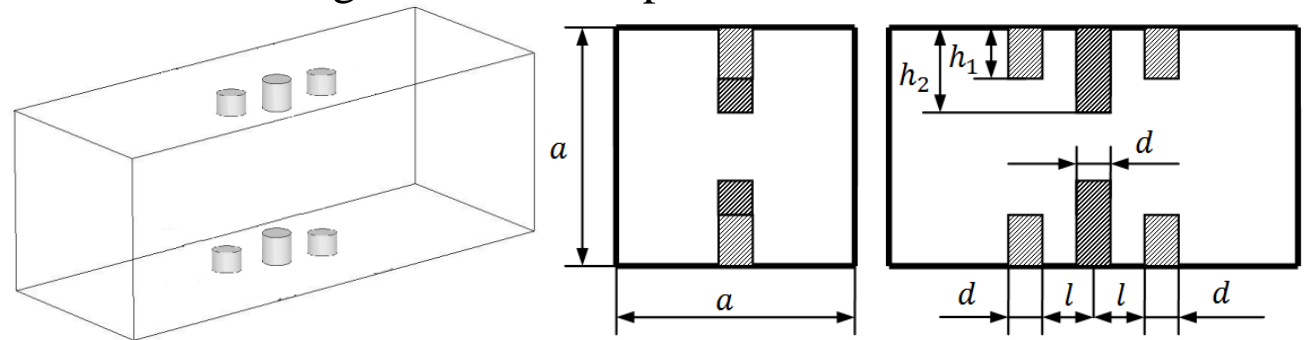

Figure. 1. Polarizer design based on a waveguide with three posts

The presence of a cylindrical post allows you to adjust the characteristics of the device by changing the length of the post.

The characteristics of the polarizer are as follows: phase, matching and polarization. Phase and matching are the differential phase shift and the voltage stand wave ratio (VSWR). The polarizing characteristics of a polarizer are the axial ratio and the crosspolar discrimination (XPD).

We form general wave matrices on the basis of the theory of microwave, having broken the circuit of the polarizer into smaller circuits

$$
\begin{gathered}
{\left[S_{\Sigma}\right]=\left[\begin{array}{ll}
S_{\sum 11} & S_{\sum 12} \\
S_{\sum 21} & S_{\sum 22}
\end{array}\right]=\frac{1}{T_{\sum 11}}\left[\begin{array}{cc}
T_{\sum 21} & |T| \\
1 & -T_{\Sigma 12}
\end{array}\right],} \\
{\left[T_{\Sigma}\right]=\left[T_{1}\right] \cdot\left[T_{2}\right] \cdot\left[T_{3}\right] \cdot\left[T_{4}\right] \cdot\left[T_{5}\right]=\left[\begin{array}{ll}
T_{\Sigma 11} & T_{\sum 12} \\
T_{\sum 21} & T_{\sum 22}
\end{array}\right],\left[T_{2}\right]=\left[T_{4}\right]=\left[\begin{array}{cc}
e^{j \theta} & 0 \\
0 & e^{-j \theta}
\end{array}\right],} \\
{\left[T_{1}\right]=\left[T_{5}\right]=\frac{1}{2}\left[\begin{array}{cc}
2+Y_{p 1} & -Y_{p 1} \\
-Y_{p 1} & 2-Y_{p 1}
\end{array}\right], \quad\left[T_{3}\right]=\frac{1}{2}\left[\begin{array}{cc}
2+Y_{p 2} & -Y_{p 2} \\
-Y_{p 2} & 2-Y_{p 2}
\end{array}\right],}
\end{gathered}
$$


where $Y_{p}$ is the conductivity of the post, $\theta$ is electric line length.

Differential phase shift is determined by the expression

$$
\Delta \varphi=\varphi_{\sum 21 . L}-\beta l \text {. }
$$

VSWR is determined by the formula

$$
V S W R=\left[1+\left|S_{11}\right|\right] /\left[1-\left|S_{11}\right|\right] .
$$

The axial ratio is determined

$$
r=10 \lg \left(\frac{A^{2}+B^{2}+\sqrt{A^{4}+B^{4}+2 A^{2} B^{2} \cos (\Delta \varphi)}}{A^{2}+B^{2}-\sqrt{A^{4}+B^{4}+2 A^{2} B^{2} \cos (\Delta \varphi)}}\right),
$$

where $A=1, B=\left|S_{21}\right|$.

XPD is calculated by the formula

$$
X P D=20 \lg \left[\left(10^{0.05 r}+1\right) /\left(10^{0.05 r}-1\right)\right] .
$$

Fig. 2 shows the matching characteristics of the mathematical model, and Fig. 3 shows the polarization characteristics of this model.

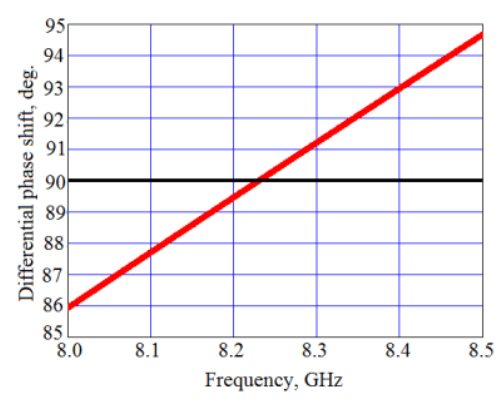

b)

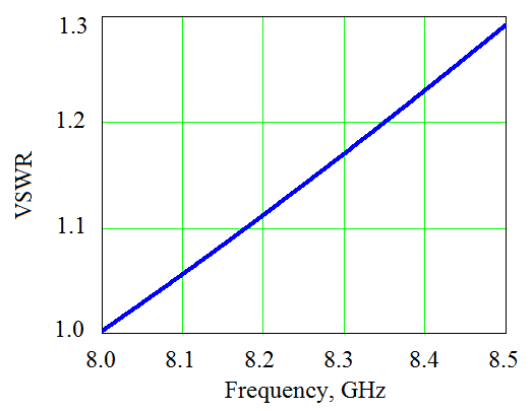

b)

Figure 2. Matching characteristics of the mathematical model

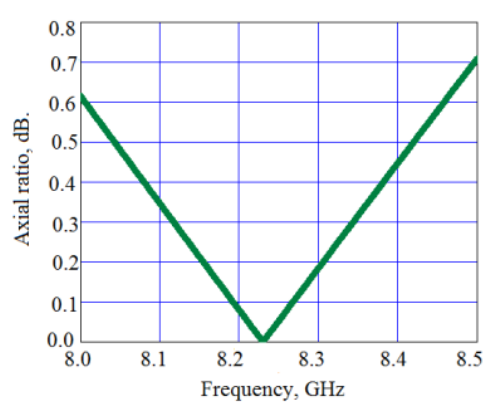

b)

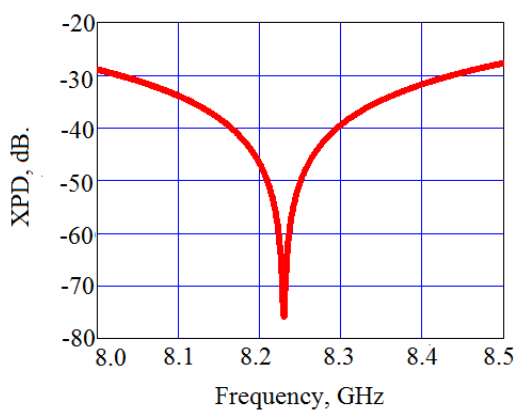

b)

Figure 3. Polarization characteristics of the mathematical model

Fig. 2a demonstrates that the maximum deviation of the differential phase shift from $90^{\circ}$ is $4.5^{\circ}$. Fig. $2 \mathrm{~b}$ shows that the maximum value of VSWR is 1.28 . Fig. 3 a contains the dependence of the axial ratio on the frequency, and Fig. $3 \mathrm{~b}$ contains the dependence of the XPD on the frequency. From fig. 3 we see that at a frequency of $8.5 \mathrm{GHz}$ the axial ratio acquires its maximum value of $0.71 \mathrm{~dB}$. Also at this frequency, the XPD acquires a maximum value of $29 \mathrm{~dB}$. 
Fig. 4 shows the matching characteristics of the polarizer. Fig. 4 a contains the dependence of the differential phase shift on the frequency, and Fig. 4 b contains the dependence of VSWR on the frequency in the operating frequency range from $8.0 \mathrm{GHz}$ to $8.5 \mathrm{GHz}$ of the studied prototype.

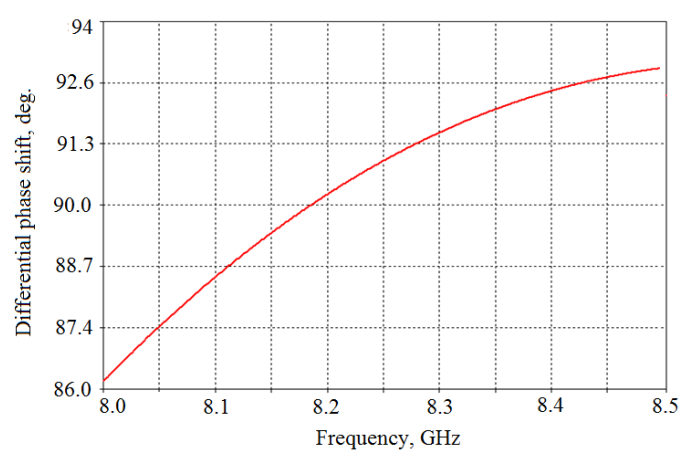

a)

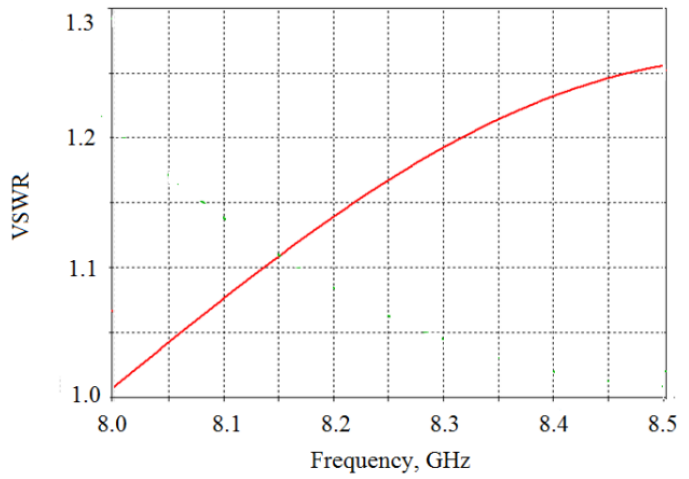

b)

Figure 4. Matching characteristics of the prototype

Fig. 4a demonstrates that the maximum deviation of the differential phase shift from $90^{\circ}$ is $4.2^{\circ}$. Fig. $4 \mathrm{~b}$ shows that the maximum value of VSWR is 1.26 .

Fig. 5 shows the polarization characteristics of the device in the operating frequency range from $8.0 \mathrm{GHz}$ to $8.5 \mathrm{GHz}$. Fig. 5 a contains the dependence of the axial ratio on the frequency, and Fig. $5 \mathrm{~b}$ contains the dependence of the XPD on the frequency. The figure shows that at a frequency of $8.0 \mathrm{GHz}$, the axial ratio acquires its maximum value of $0.55 \mathrm{~dB}$. Also at this frequency, the XPD acquires a maximum value of $31 \mathrm{~dB}$.

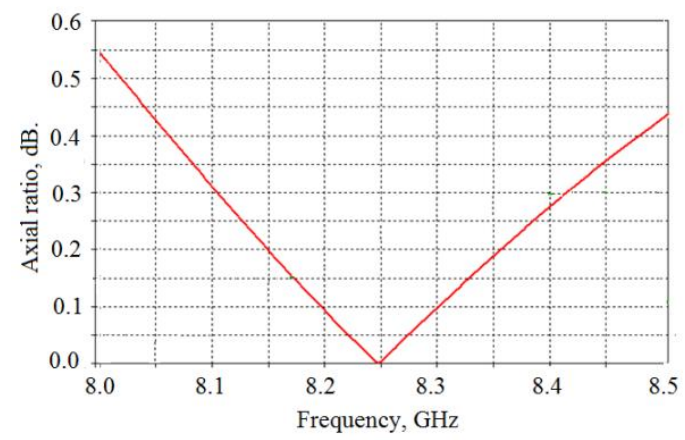

b)

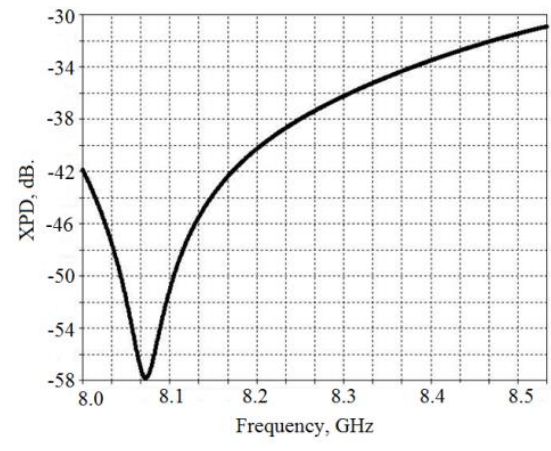

b)

Figure 5. Polarization characteristics of the prototype

Such characteristics provide the optimal design of the polarizer, which are presented in table 1.

Table 1. Optimal characteristics of the polarizer

\begin{tabular}{|c|c|c|c|c|}
\hline $\boldsymbol{a}, \mathbf{m m}$ & $\boldsymbol{l}, \mathbf{m m}$ & $\boldsymbol{h}_{\boldsymbol{1}}, \mathbf{m m}$ & $\boldsymbol{h}_{\mathbf{2}}, \mathbf{m m}$ & $\boldsymbol{d}, \mathbf{m m}$ \\
\hline 30.0 & 2.92 & 2.0 & 4.28 & 2.0 \\
\hline
\end{tabular}

As you can see, the matching and polarization characteristics of the mathematical model and prototype simulated in CST Microwave Studio coincide with the corresponding accuracy. 
Thus, the developed waveguide polarizer with three posts has the following characteristics. The range of change of the differential phase shift is $90^{\circ} \pm 4.2^{\circ}$. The polarizer provides VSWR less than 1.26. Axial ratio is less than $0.55 \mathrm{~dB}$. XPD is higher than $31 \mathrm{~dB}$.

\section{References}

1. Zhu Q.C. Reactance of posts in circular waveguide / Q.C. Zhu, A.G. Williamson, M.J. Neve// IEEE Transactions on Microwave Theory and Techniques. - 2007. - Vol. 55, No. 8. - pp. 1685-1688. DOI: 10.1109/TMTT.2007.901605.

2. Piltyay S.I. Waveguide iris polarizers for $\mathrm{Ku}$-band satellite antenna feeds / S.I. Piltyay, A.V. Bulashenko, I.V. Demchenko // Journal of Nano- and Electronic Physics. 2020. - Vol. 12, no. 5. - pp. 05024-1-5. DOI: http://doi.org/10.21272/jnep.12(5).05024.

3. Bulashenko. Analytical technique for iris polarizers development / A.V. Bulashenko, S.I. Piltyay, I.V. Demchenko // IEEE International Conference on Problems of Infocommunications. Science and Technology, Kharkiv, Ukraine. - 2020. - pp. 471-476.

4. Piltyay S.I. Compact polarizers for satellite information systems / S.I. Piltyay, A.V. Bulashenko, I.V. Demchenko // IEEE International Conference on Problems of Infocommunications. Science and Technology, Kharkiv, Ukraine. - 2020. - pp. 317-322.

5. Tribak A. Ultra broadband low axial ratio corrugated quad-ridger polarizer / A.Tribak, A. Mediavilla, et al. // European Microwave Conferences, Rome, Italy. - October 2009. - pp. 284-287. DOI: http://doi.org/10.23919/EUMC.2009.5295927.

6. Dubrovka F.F. Optimum septum polarizer design for various fractional bandwidths / F.F. Dubrovka, S.I. Piltyay, et al. // Radioelectronics and Communications Systems - 2020. Vol. 63, no. 1. - pp. 15-23. http://doi.org/10.3103/I07352720010021.

7. Dubrovka F. Compact X-band stepped-thickness septum polarizer / F. Dubrovka, S. Piltyay, O. Sushko, et al. // IEEE 12th Int. Conf. on Antenna Theory and Techniques. Kharkiv, Ukraine, 2020, pp. 135-138.

8. Kirilenko A.A. A tunable compact polarizer in a circular waveguide / A.A. Kirilenko, S.O. Steshenko, et al. // IEEE Transactions on Microwave Theory and Techniques. - 2019. Vol. 67, No. 2. - pp. 592-596. DOI: 10.1109/TMTT.2018.2881089.

9. Пільтяй С.I. Напівеліптичний широкосмуговий фазозсувач / C.I. Пільтяй, А.В. Булашенко, I.О. Мосьондз // Матеріали всеукраїнської науково-практичної інтернетконференції «Молодь в науці: дослідження, проблеми, перспективи». - Вінниця: ВНТУ, 18-29 травня 2020. - С. 365 - 368.

\section{Анотація}

Представлені результати розробки регульованого поляризатора на основі квадратного хвилеводу із трьома штирями. Розроблений поляризатор працює в діапазоні від 8.0 ГГЦ до 8.5 ГГц.

Ключові слова: поляризатор, діафрагма, штир, хвилевод.

\section{Abstract}

The results of the development of a tunable polarizer based on a square waveguide with three posts are presented. The developed polarizer operates in the range from $8.0 \mathrm{GHz}$ to 8.5 $\mathrm{GHz}$.

Keywords: polarizer, iris, post, waveguide. 